How might tuberculosis chemotherapy induce hyperglycaemia? In patients taking rifampicin for tuberculosis Japanese investigators obtained normal results for intravenous glucose tolerance but hyperglycaemia after oral glucose. ${ }^{10}$ No such effect was seen with other agents including isoniazid, ethambutol and streptomycin. These workers suggested that rifampicin either augments intestinal absorption of glucose or reduces insulin sensitivity.

\title{
REFERENCES
}

1 Chan JC, Cockram CS, Critchley JA. Drug-induced disorders of glucose metabolism. Mechanisms and management. Drug Saf 1996; 15:135-57

2 Kane JM, Barrett EJ, Casey DE, et al. Metabolic effects of treatment with atypical antipsychotics. J Clin Psychiatry 2004;65:1447-55

3 Woerle HJ, Mariuz PR, Meyer C, et al. Mechanisms for the deterioration in glucose tolerance associated with HIV protease inhibitor regimens. Diabetes 2003;52:918-25

4 Basoglu OK, Bacakoglu F, Cok G, Sayiner A, Ates M. The oral glucose tolerance test in patients with respiratory infections. Monaldi Arch Chest Dis 1999;54:307-10

5 Ismail Y. Pulmonary tuberculosis - a review of clinical features and diagnosis in 232 cases. Med J Malaysia 2004;59:56-64

6 Ponce-De-Leon A, Garcia-Garcia Md Mde L, Garcia-Sancho MC, et al. Tuberculosis and diabetes in southern Mexico. Diab Care 2004;27:1584-90

7 Kihara Y, Otsuki M. Interaction of gliclazide and rifampicin. Diab Care 2000;23:1204-5

8 Self TH, Tsui SJ, Fowler JW. Interaction of rifampin and glyburide. Chest 1989;96:1443-4

9 Atkin SL, Masson EA, Bodmer CW, Walker BA, White MC. Increased insulin requirement in a patient with type 1 diabetes treated with rifampicin. Diab Med 1993;10:392

10 Takasu N, Yamada T, Miura H, et al. Rifampicin-induced early phase hyperglycemia in humans. Am Rev Respir Dis 1982;125:23-7

\section{Use of rituximab in two unusual antibody-mediated autoimmune disorders}

\section{Matthew Adler BSc MRCP Fotini Soliotis BSc MRCP Sonali Thakrar BSC Richard Stratton MD FRCP}

J R Soc Med 2005;98:271-272

In immune disorders characterized by specific autoantibody production, conventional immunosuppressive therapy can be unsatisfactory. When the illness is life threatening, B-cell depletion with a monoclonal antibody offers an additional strategy.

Rheumatology Department, Royal Free Hospital, London NW3 2QG, UK

Correspondence to Dr Richard Stratton

E-mail:r.stratton@medsch.ucl.ac.uk

\section{CASE HISTORIES}

\section{Case 1}

A month after undergoing breast reduction surgery an AfroCaribbean aged 17 experienced a widespread burning erythematous rash, arthralgias, fatigue, fevers, alopecia, anorexia and weight loss. There was no history of Raynaud's syndrome, mouth ulcers or photosensitivity; her mother had systemic lupus erythematosus. On examination there was a widespread urticarial vasculitis and her temperature was $39^{\circ} \mathrm{C}$. Enlarged lymph nodes were present in the cervical and inguinal regions and she had knee effusions and synovitis.

Blood tests were as follows: antinuclear factor persistently negative, haemoglobin $10.8 \mathrm{~g} / \mathrm{dL}$, white blood cells $6.5 \times 10^{6} / \mathrm{L}$, platelets $457 \times 10^{9} / \mathrm{L}$, erythrocyte sedimentation rate $(E S R) 57 \mathrm{~mm} / \mathrm{h}$, C-reactive protein $200 \mathrm{mg} / \mathrm{dL}, \mathrm{C} 3186 \mathrm{mg} / \mathrm{dL}$ (reference range 70-165), C4 $13 \mathrm{mg} / \mathrm{dL}$ (16-54), biochemical results normal apart from lactate dehydrogenase $1340 \mathrm{IU} / \mathrm{L}$. On CT of the chest, abdomen and pelvis there was extensive lymphadenopathy, and biopsy of a node showed reactive lymphoid hyperplasia. On skin biopsy the presence of perivascular neutrophils with nuclear fragmentation was consistent with urticarial vasculitis. Further antibody testing showed positive anti$\mathrm{C} 1 \mathrm{q}$ antibody, $32 \mathrm{U} / \mathrm{mL}(0-15)$. With a diagnosis of hypocomplementaemic urticarial vasculitis syndrome (HUVS) ${ }^{1}$ she was started on prednisolone $15 \mathrm{mg}$ and hydroxychloroquine $200 \mathrm{mg}$ daily but remained unwell with anaemia, ESR $>90 \mathrm{~mm} / \mathrm{h}$, arthritis and worsening of the rash. C4 was persistently low despite treatment with high-dose methylprednisolone and immunosuppressive drugs including azathioprine and mycophenolate mofetil. She showed signs of respiratory involvement - a grave complication of HUVS ${ }^{1}$ — with exertional dyspnoea and a restrictive ventilatory deficit.

In view of the severity of her disease she was treated with four weekly infusions of the anti-CD20 monoclonal antibody rituximab at a dose of $375 \mathrm{mg} / \mathrm{m}^{2}$. Her condition went into remission and the dose of prednisolone was tapered from $30 \mathrm{mg}$ to $12.5 \mathrm{mg}$ per day, in combination with mycophenolate mofetil $500 \mathrm{mg}$ twice daily. At followup six months after rituximab treatment she was well, without rash or synovitis. Her $\mathrm{C} 4$ was now almost normal at $16 \mathrm{mg} / \mathrm{dL}$ and her anti-C1q had fallen to $23 \mathrm{U} / \mathrm{mL}$.

\section{Case 2}

2 years after the onset of systemic lupus erythematosus an Afro-Caribbean woman of 41 experienced a severe flare of disease with synovitis, peripheral lymphadenopathy and a facial discoid rash. Blood tests showed pancytopenia and dsDNA antibodies $(>500 \mathrm{IU} / \mathrm{mL})$. She responded to intravenous methylprednisolone $(1.5 \mathrm{~g})$ and cyclophosphamide 
(750 mg) but was then found to have a random blood glucose in the diabetic range $(>20 \mathrm{mmol} / \mathrm{L})$. This was initially attributed to the steroid therapy but over the next two weeks the diabetes became increasingly difficult to control, with plasma glucose $10-20 \mathrm{mmol} / \mathrm{L}$ despite insulin infusion of over 800 units $/ 24 \mathrm{~h}$. In addition there had been a change in physical appearance with complete loss of subcutaneous fat and hirsutism.

When found to have high titres of antibody to the insulin receptor but no antibodies to insulin she was diagnosed as having the syndrome of type B insulin resistance. ${ }^{2}$ She then received four weekly intravenous doses of rituximab $580 \mathrm{mg}$. There were no obvious side effects and a month after the start of treatment her peripheral B-cell count had fallen by $94 \%$ (T-cell count unchanged). The ESR declined from 116 to $9 \mathrm{~mm} / \mathrm{h}$. Reduction of the insulin dosage was then begun. Two months after the treatment, daily insulin was about 300 units and blood glucose was $5-12 \mathrm{mmol} / \mathrm{L}$. At three months her daily insulin requirement had fallen to 120 units and at five months she was able to stop insulin therapy. Over this period the fat atrophy resolved and her facial appearance returned to normal.

\section{COMMENT}

In these two patients, the production of well-defined autoantibodies led to severe life-threatening disease that proved resistant to strong immunosuppressive drugs. Originally used in the treatment of B cell lymphomas, ${ }^{3}$ rituximab has lately found a place in management of autoimmune disorders such as rheumatoid arthritis and systemic lupus erythematosus. ${ }^{4,5}$ The B-cell-depleting effect results from complement and antibody dependent cell mediated cytotoxicity, inhibition of cell proliferation and induction of apoptosis of CD20 expressing cells of the Bcell lineage. Lack of expression of CD20 on progenitor cells means that rituximab can deplete peripheral $\mathrm{B}$ cells without robbing the bone marrow of progenitor cells. The agent is well tolerated: neutropenic sepsis has been described, ${ }^{6}$ but major infections seem uncommon after its use in rheumatic disease. ${ }^{4}$ Clinicians should consider rituximab therapy when faced with severe antibody-mediated autoimmune conditions resistant to conventional immunosuppressive drugs.

\section{REFERENCES}

1 Wisnieski JJ, Baer AN, Christensen J, et al. Hypocomplementemic urticarial vasculitis syndrome. Clinical and serologic findings in 18 patients. Medicine (Baltimore) 1995;74:24-41

2 Arioglu E, Andewelt A, Diabo C, Bell M, Taylor SI, Gorden P. Clinical course of the syndrome of autoantibodies to the insulin receptor (type $\mathrm{B}$ insulin resistance): a 28-year perspective. Medicine (Baltimore) 2002;81:87-100

3 Grillo-Lopez AJ, Hedrick E, Rashford M, Benyunes M. Rituximab: ongoing and future clinical development. Semin Oncol 2002;29(suppl 2): $105-12$
4 Edwards JC, Cambridge G. Sustained improvement in rheumatoid arthritis following a protocol designed to deplete B lymphocytes. Rheumatology (Oxford) 2001;40:205-11

5 Perrotta S, Locatelli F, La Manna A, Cennamo L, De Stefano P, Nobili B. Anti-CD20 monoclonal antibody (Rituximab) for life-threatening autoimmune haemolytic anaemia in a patient with systemic lupus erythematosus. Br J Haematol 2002;116:465-7

6 Chaiwatanatorn K, Lee N, Grigg A, Filshie R, Firkin F. Delayed-onset neutropenia associated with rituximab therapy. Br $J$ Haematol 2003; 121:913-18

\section{Hearing loss treated with pamidronate}

\author{
Louisa Murdin MRCP Lam Hoe Yeoh FRCS
}

J R Soc Med 2005;98:272-274

Elderly patients who attend an audiology department for hearing loss are commonly found to have a treatable cause. ${ }^{1}$

\section{CASE HISTORY}

A retired army quartermaster aged 72 sought advice because of hearing loss and tinnitus reminiscent of Morse code. He also reported an increase in regimental beret size from $6 \frac{3}{4}$ inches to $7 \frac{1}{2}$ inches. This classic detail of the history prompted measurement of serum alkaline phosphatase, which was high at $562 \mathrm{u} / \mathrm{L}$ (corrected calcium $2.35 \mathrm{mmol} / \mathrm{L}$ ). The diagnosis of Paget's disease was confirmed by isotope bone scan.

MRI of his brain and internal acoustic meati confirmed skull vault thickening and showed no evidence of compression of the 8th cranial nerve on either side. The cochleas appeared normal. His audiogram showed the moderate mixed high-frequency sensorineural and lowfrequency conductive hearing loss typical of Paget's disease. Tympanograms were normal, and loudness discomfort levels suggested a non-recruiting loss. He was treated with six intravenous pamidronate infusions at one-week intervals and was provided with a hearing aid. At reassessment six months later the conductive component of his hearing loss had completely resolved and in consequence air conduction thresholds had improved (Figure 1). He no longer required the hearing aid. His tinnitus had greatly improved, and the alkaline phosphatase was now $198 \mathrm{u} / \mathrm{L}$.

Department of Audiology, St Helier Hospital, Carshalton SM5 1AA, UK

Correspondence to: Louisa Murdin

E-mail: louisa@murdin.com 